"Municipalities, commercial composting and sustainable development, the case of Johannesburg , South Africa"

\begin{tabular}{ll} 
AUTHORS & $\begin{array}{l}\text { Rethabile Sehlabi } \\
\text { Tracey Morton McKay } \\
\text { Rethabile Sehlabi and Tracey Morton McKay (2016). Municipalities, commercial } \\
\text { ARTICLE INFO }\end{array}$ \\
\hline Africa. Environmental Economics, 7(1), 53-59. doi: 10.21511/ee.07(1).2016.07 \\
\hline DOI & http://dx.doi.org/10.21511/ee.07(1).2016.07 \\
\hline RELEASED ON & Thursday, 24 March 2016 \\
\hline JOURNAL & "Environmental Economics" \\
\hline FOUNDER & LLC "Consulting Publishing Company "Business Perspectives"
\end{tabular}

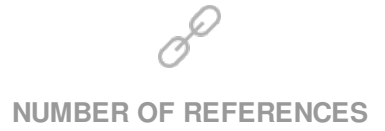

0

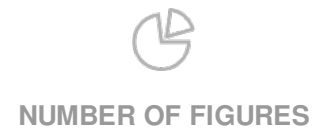

0

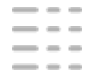

NUMBER OF TABLES

0

(C) The author(s) 2023. This publication is an open access article. 


\title{
Municipalities, commercial composting and sustainable development, the case of Johannesburg, South Africa
}

\begin{abstract}
Typical of most developing world cities, the City of Johannesburg, South Africa, faces many waste management challenges. One of which is a lack of awareness of, and compliance with, waste management legislation, recycling and composting by the general public. Thus, the city has to deal with high levels of solid waste generation and subsequent pressure on its landfill sites. The city also has to adhere to various pieces of waste management legislation, with recycling and composting being two essential elements thereof. This study outlines a commercial composting initiative designed by the municipality of Johannesburg to redirect organic green waste from landfill sites to a compost production plant. The study found that although the Panorama Commercial Composting Plant is reducing the amount of solid organic waste disposed of in the city's landfills, better planning could increase the amount of green organic waste thus diverted. Furthermore, the adoption of a centralized, mechanized system has significantly hampered the generation of employment opportunities, while simultaneously forcing operational costs up. Finally, the lack of a coherent marketing and branding strategy has restricted compost sales. Thus, the Panorama Commercial Composting Plant is currently not recouping its costs nor generating the number of work opportunities it could. Some recommendations to rectify this are then made.
\end{abstract}

Keywords: commercial composting, South Africa, appropriate technology, job opportunities, sustainable development. JEL Classification: Q580.

\section{Introduction}

Like many developing world cities, the City of Johannesburg faces a number of solid waste management challenges. More people with more disposal income are causing rates of solid waste generation to increase annually, despite the city lacking sufficient landfill sites, many of which were also not well maintained in the past (van de Klundert \& Lardinois, 1995; Ekelund \& Nyström, 2007; Troschinetz \& Michelcic, 2009; PIKITUP Annual Report, 2007/8). Although there are inaccuracies and gaps in the data, it is accepted that waste volumes in Johannesburg increased to an average of 1.2 million tonnes per annum in 2011/12 (PIKITUP Annual Report, 2011/12). Furthermore, the cost of transporting solid waste and managing landfill sites is escalating (PIKITUP Annual Report 2011/12). In general, Johannesburg residents perceive solid waste as having no economic value so they seldom prioritize solid waste management and are generally unaware of the benefits and importance of waste separation (CoJ, 2003a). Thus, waste is seldom separated at source, which inhibits recycling/ composting. Unfortunately, manual separation after collection raises overhead costs, causes cross contamination (which further increases costs) and reduces the value of recyclables. This situation is contrary to the notion of sustainable development (Yiğiter \& Yirmibeşoğlu, 2011). It is also a situation found in many other developing countries (Onu, 2000; Mbuligwe et al., 2002). This study seeks to contribute to the literature by investigating a commercial composting

(c) Rethabile Sehlabi, Tracey Morton McKay, 2016.

Rethabile Sehlabi, M.Sc., Senior Environmental Advisor, Eskom, Johannesburg, South Africa.

Tracey J.M. McKay, M.A., Senior Lecturer Department of Environmental Sciences, University of South Africa, South Africa. launched in Johannesburg. There is little written on commercial composting in African cities, or the developing world cities for that matter, save for some studies undertaken in Bangladesh, India, Cuba and Brazil. The study takes the following form. Firstly the international situation with respect to composting in developing countries is outlined, with lessons learnt from the international experience summarized. Then the research methodology is described, followed by the legislative framework pertaining to composting in South Africa is provided. The study site is then described, along with the landfill site situation in South Africa. Finally the municipal composting plant and the challenges its faces, are outlined. Recommendations are then made.

\section{Commerical compositing in other developing countries}

Commercial composting can be practised using either a centralized or a decentralized system. In a centralized system, organic material is collected in bulk and taken to a central composting plant, from where it is passed on to a landfill site after it has gone through reduction and biological stabilization processes. Decentralized processes work the same way but at multiple sites, usually operating on a smaller scale. Most developing countries, such as Brazil, Bangladesh and India have decentralized commercial composting, with Cuba being an exception. Initially, centralized composting was integral to Cuba's solid waste management system. However, Cuba is moving to decentralized system due to the high costs of its centralized system. In addition, Cuba faces fuel shortages, equipment malfunctions and inadequate maintenance of machinery, all of which cause costs to further escalate. Cuba, therefore, hopes that decentralized composting plants will re- 
duce financial pressure on the waste collection and transport systems and increase the availability of organic fertiliser (Korner et al., 2008).

Dhaka, Bangladesh, has achieved a reasonable measure of success with a decentralized composting system that uses the Indonesian Windrow Technique. As for Johannesburg, Dhaka decided to deal with increased solid waste generation, urban sprawl and a shortage of landfills by opting for organic waste recovery through composting, albeit with some crucial differences. The commercial composting project enjoyed national Bangladeshi government support as composting was viewed as a way to improve soil quality. From the start, in 1998, commercial composting was a publicprivate partnership between the local city government, an NGO (called Waste Concern) and the private sector. The municipality provided free land for the processing of the waste. Waste Concern employs community members (mostly women) to manually collect, separate, generate and package the compost. Thus, costs are kept low and the small payments made by households for collection also help towards cost recovery (Zurbrugg et al., 2004 and 2005). Marketing and sales are carried out by private sector organizations - who add nutrients to the product in order to enhance sales. Most compost is sold to farmers who form part of the well-established urban and peri-urban agricultural market. The system is successful, with huge quantities of organic waste recovered from the waste stream. Job opportunities have been generated and costs are low (Zurbrugg et al., 2005).

Curitiba, Brazil has by-laws mandating waste separated into organic and inorganic material. Local residents willingly do this, as Brazil's long history of military dictatorship has fostered a culture of legal compliance. Recycling plays a crucial role in the local economy, providing much needed jobs, as inorganic-waste-sorting plants purposefully employ the economically marginalized, such as immigrants and the disabled. Residents of informal settlements can exchange bags of separated waste for bus tickets or food parcels, further driving local buy-in. Lastly children are trained in recycling at school so as to drive waste separation at home (Lerner, 1995).

As is the case for many developing countries, organic waste makes up between 40 and $85 \%$ of the solid waste stream in India. There was a long tradition of composting in rural India, so, in 1970s, developmental organizations built on this by establishing large, centralized composting plants. However, most proved to be uneconomical and are no longer operational (Zurbrugg et al., 2003). Their failure was primarily due to high operating and transport costs, coupled with poorly developed compost markets and cross contamination which makes the compost undesirable to farmers. In the $1990 \mathrm{~s}$, a new composting trend evolved with the rise of small, manually-operated, community-based composting plants. These were often spontaneous initiatives backed by citizens and non-governmental organizations, although a few were funded by international aid organizations. With decentralized plants, operational costs are much lower as there are no large machines to buy or maintain. Unskilled jobs are generated and, as organic waste is composted close to where it is generated, transport costs are minimal. However, the composting plants face serious marketing challenges. The Indian government has yet to make a concerted effort to devise convincing marketing strategies for the product. It is also hard to compete with inorganic compost, which is heavily subsidized by the Indian government. The composting plants also face serious competition from cheap cow dung and poultry manure (Zurbrugg et al., 2004). Perception is another hurdle. Few farmers trust the product, preferring tried and tested traditional products.

\section{Lessons learnt from the international experience}

International initiatives demonstrate that small scale decentralized community initiatives are more likely to meet with success and achieve sustainable development goals. Decentralized composting plants promote robust recycling and are cheaper to operate. Centralized, mechanized plants have proven to be economically unviable and not fit for the socio-economic conditions that prevail in the developing world, due to high running costs, maintenance requirements and the need for costly skilled labour. The Farooq Composting Plant in Karachi, Pakistan, for example, was closed in part due to mechanical failure (Zurbrugg et al., 2004 and 2005). The Dhaka and Indian composting purposefully use labor-intensive methods to create job opportunities for the unskilled, vulnerable and marginalized (Drescher \& Zurbrugg, 2006). Overall, the success of commercial composting is linked to public recognition of the economic value of compost, cheap waste separation practices, and encouraging waste separation at source (Deshmukh et al., 2002). Furthermore, public-private partnerships seem to present a suitable way forward for composting plants (des Ligneris, 2000). This is particularly necessary with respect to marketing, which can mean the difference between commercial success and failure (Hoornweg et al., 1999).

\section{Research aims and methodology}

The purpose of this study was to establish how successful the Panorama Commercial Composting Plant was. The study had a number of research questions: (1) Are organics being diverted to the Panorama Pilot Plant? (2) Does the Panorama Pilot Composting Plant generate employment opportuni- 
ties? and (3) Is the plant financially sustainable? Data were collected from the following sources: (a) site visits to the composting plant and garden refuse sites for the purposes of observation; (b) analysis of Johannesburg's annual reports and other documentation as well as (c) semi-structured in-depth interviews with key personnel in the City of Johannesburg, at the composting plant and within the composting and garden refuse site community, using non-probability, snowball sampling. All participation was voluntary and participants gave informed consent. The study has a number of limitations. Firstly, due to the paucity of secondary data, the data gathering period was extensively drawn out in terms of time. Secondly, not all of the stakeholders at the various garden refuse sites were interviewed due to time and financial constraints. Thirdly, some of the official secondary data (from the PICKITUP Annual Reports) were clearly inaccurate as tonnages are recorded as the same for two different years and/or official data are simply missing.

\section{The planning and legislative framework for composting in South Africa}

In order to better manage the solid waste stream, Johannesburg embarked on a waste management planning and review process (Ekelund \& Nyström, 2007). This process involved public participation sessions, environmental impact assessments and data collection (CoJ, 2003b). An analysis of Johannesburg's solid waste stream demonstrated that more than half was organic material - from household gardens, lawns, parks and sports fields (Giggey et al., 2000; CoJ, 2003a; Fehr, 2007). So, composting this material would save landfill airspace, reduce transport costs and, through sales of the endproduct, increase municipal income (Giggey et al., 2000; Ekelund \& Nyström, 2007). Furthermore, composting would help the city begin to meet the requirements of the so-called 'Polokwane Declaration'. The Polokwane Declaration emanated from the First National Waste Summit, held in Polokwane, Limpopo, 2001, where all three spheres of government (national, provincial and local); civil society; and the business community were represented (Daile, 2010; Lloyd, 2010). The summit called for urgent action to reduce, re-use, and recycle waste in order to achieve sustainable development and improve quality of life in South Africa. The declaration listed specific goals: (1) stabilizing solid waste generation rates, (2) halving solid waste disposal rates by 2012, and (3) achieving ZERO waste by 2020 (DEAT, 2001).

In addition, commercial composting is supported by a strong legislative framework. That is, the Johannesburg has to comply with a vast array of legal regulations pertaining to solid waste management:
The Constitution; The National Environmental Management Act (NEMA) No. 107 of 1998; The National Environmental Waste Act (NEWA) No. 59 of 2008; The Municipal Systems Act of No. 32 of 2000 and The Health Act (No. 63 of 1977). NEMA sets specific solid-waste-related principles: (a) the avoidance and minimization of waste, (b) the remediation of pollution, (c) the reduction, re-use and recycling of waste, (d) the proper disposal of waste, (e) a cradle-to-grave philosophy and (f) the "polluter-pays" principle. So, Johannesburg is legally compelled to support composting (Bhorat et al., 2004; Blignaut et al., 2004). To this end, then, a pilot commercial composting plant - see Figure 1 was established at Panorama (Otieno \& Venter, 2004). Johannesburg decided that success would be determined by how much garden waste was diverted away from landfills to the commercial composting plant, with an initial target set at $25 \%$. It is for this reason, then, that this study turns to exploring some of the problems facing the landfills of Johannesburg.

\section{Landfill issues pertaining to the city of Johannesburg}

In Johannesburg most solid waste is disposed of across six landfill sites. Four of them belong to a public-private entity, PIKITUP, Johannesburg's official waste management service provider. PIKITUP was founded in January 2001 and the municipality is the main shareholder. PIKITUP's four landfills are Robinson Deep, Goudkoppies, Ennerdale and Marie Louise. Two other landfills, Chloorkop and Mooiplaats, are privately owned (CoJ, 2003a). All the landfills are under pressure but the lack of potential landfill sites located far from new or planned residential developments, are minimal. Thus, slowing the pace at which landfill airspace is filled is crucial (PIKITUP Annual Report, 2007/8; $2008 / 9 ; 2009 / 10 ; 2010 / 11 ; 2011 / 12$ ). Almost all of the landfill sites face design problems. These include: ineffective access control; insufficient drainage; no liner design; inadequate capping for the completed portions of the landfills, and in some cases, inadequate water quality monitoring systems (CoJ, 2003b). Members of the public complain about poor operational practices. For example, records from weigh-bridges are often inaccurate, computers are not always operational and staff inadequately-trained. Theft of computer equipment, telephone lines and electric cables is a regular occurrence. The landfills also accept building rubble, at no cost and so it isn't weighed or recorded, as it is used as covering material (PIKITUP Annual Report, 2007/8; 2008/9; 2009/10; 2010/11; 2011/12). Poor operational practices are complicated by the presence of waste reclaimers, who illegally collect recyclables from the landfill sites to sell to survive. As 
salvaging interrupts landfill operations and poses considerable health and safety risks to the salvagers, salvaging is discouraged by directives from The Minimum Requirements for Waste Disposal by Landfill (Department of Water Affairs and Forestry, 1998), and from The National Waste Management Strategy (Department of Environmental Affairs and Tourism, 1998). Enforcing these directives is not easy, and the informal salvaging continues. It is clear then, that composting could enable Johannesburg to reduce pressure on its landfills.

\section{The panorama composting plant: the composting process and opertions}

The Panorama Composting Plant was commissioned in 1995, became operational in 2003, and is currently owned and operated by PIKITUP (Diale, pers comm, 2010). It uses a highly mechanized, centralized aerobic composting system (Lloyd, pers comm, 2010). The composting process used at Panorama comprises of a milling, windrow formation and screening phase. During the composting process, the plant makes use of German equipment, including a milling machine, a loader, an 1800 compo-screen, a Rhino SP4 windrow turner, and a compost shredder MZA-2500 to produce the compost (Venter, pers comm, 2006; Shoemaker, pers comm, 2006). The equipment fails from time to time which halts the production process, as parts must be imported (Makhubela, pers comm, 2010; Singo, pers comm, 2010; PIKITUP Annual Report, 2010/11 and 2011/12). As the equipment was bought without a maintenance contract, all repair costs fall to PIKITUP. Once the six-month composting process is complete, the compost is packaged into bags. The plant offers discounts for bulk purchases, as well as discounts if compost is purchased on site. A delivery service is also available. A variety of products are on sale, namely compost, unscreened compost, mulch, potting soil, and a compost/topsoil mix. The plant faces serious competition from the well established private composting sector (Singo, pers comm, 2010).

\section{The panorama composting plant: operation and human resource challenges}

The composting plant has a staff complement of 17 . An additional staff member, who resigned, has not been replaced as a cost-cutting measure. The employees include five plant operators, 12 laborers and one driver. All of the employees, bar two, are black people, with the majority being over the age of 31 . There are two white male employees (both senior staff) and four female employees. Most of the staff members are unskilled, lacking in any formal job-specific training. Operational costs are high due to staff and transport costs, and the plant is inefficient. The machinery is hard to maintain and the site has water logging problems (Venter, pers comm, 2006; Lloyd, pers comm, 2010; PIKITUP Annual Report, 2010/11). The organics are mainly sourced from garden refuse sites located within the municipal boundaries of Johannesburg (see Figure 1). However, the plant also accepts garden waste from the general public, from other landfills, from garden service enterprises, landscaping firms and tree fellers. PIKITUP is currently debating whether manure should be added during the process to improve the quality of the compost, but concerns about odour are holding this initiative back (Diale, pers comm, 2010; Lloyd, pers comm, 2010; Singo, pers comm, 2010).

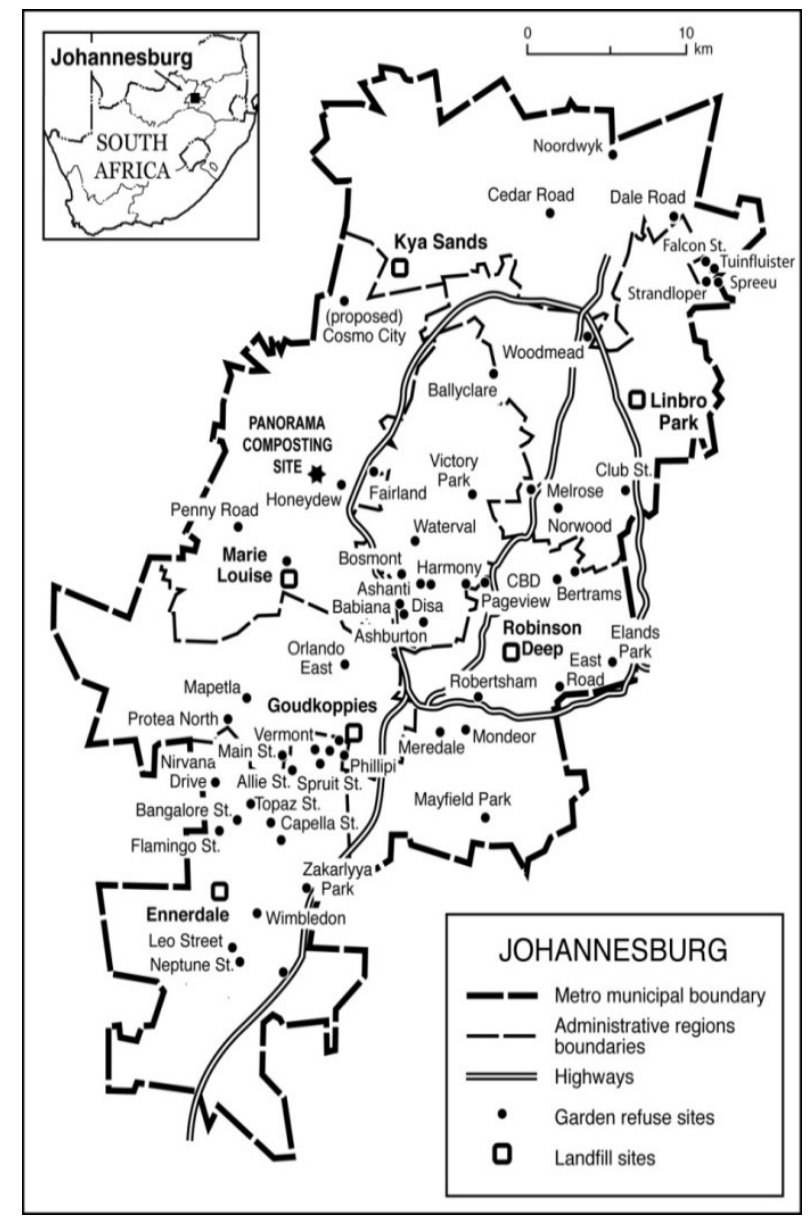

Fig. 1. Map of the City of Johannesburg showing the Panorama Composting Plant, the landfill sites and the garden refuse sites

Initially, the Panorama Plant received approximately 1 000 tonnes of green waste per month, but this has steadily increased. Some months are low, at 1000 tonnes, but in other months record up to 11000 tonnes, depending on the season and business cycles (Diale, pers comm, 2010; Lloyd, pers comm, 2010). The supply is heavily seasonal as Johannesburg is a summer rainfall area (Makhubela, pers comm, 2010; Singo, pers comm, 2010). By 2007/8, a total of 61140 tonnes were delivered to the plant, exceeding its design capacity of 40000 tonnes (PIKITUP Annual Report, 
2007/8). As can be seen in Table 1, however, data collection is a challenge. For example, the $2007 / 8$ and 2008/9 annual reports both reflect the same tonnage of green waste collected at the Panorama Plant, while for $2009 / 10$ no tonnage data are available at all. Not all the revenue data are available either.

Table 1. Annual tonnage of green garden waste and revenue generated by the Panorama Plant

\begin{tabular}{|l|c|c|c|c|c|}
\hline \multicolumn{1}{|c|}{ Year } & $2007 / 8$ & $2008 / 9$ & $2009 / 10$ & $2010 / 11$ & $2011 / 12$ \\
\hline Total waste tonnage & 1575948 & 1099439 & 1266385 & 1123494 & 1294045 \\
\hline Panorama tonnage & 61140 & 61140 & No data & 57211 & 46299 \\
\hline Revenue & No data & USD 290 100 & USD 157 300 & USD 109 414 & USD 46 900 \\
\hline
\end{tabular}

Source: PICKITUP Annual reports 2007/8; 2008/9; 2009/10; 2010/11; 2011/12. Note that 1 USD = approximately 7.75 between 2007 and 2012.

Despite the missing data, the Panorama plant employees maintain that between 12 to $15 \%$ of the total amount of green waste produced in the city goes to the composting plant (Lloyd, pers comm, 2010). Such high figures are unlikely, as PIKITUP reports a total of roughly 4 percent. On average some 56448 tonnes of organic waste are processed into compost at Panorama, generating revenues of R1 509286 (on average) per annum. This is clearly below the target of $25 \%$. Thus, in order to increase the quantities of waste at the Panorama Plant, plans are in place for additional organic material to be diverted from other garden refuse sites in Johannesburg, as well as from the landfill sites themselves. PIKITUP plans to install waste transfer stations at additional garden refuse sites to boost material flow to the composting facility. Municipal managers are also investigating ways in which more park waste from City Parks can be redirected to Panorama (Shoemaker, pers comm, 2006). Lastly, PIKITUP plans to open four additional composting plants on existing landfill sites (e.g. Linbro Park) (Venter, pers comm, 2006; Lloyd, pers comm, 2010). To date, none of this has occurred, ostensibly due to a lack of funds. Some would like to see private investors buying into the plant (Lloyd, pers comm, 2010). Two aspects, namely diversifying the compost products and finding more customers, have been identified as a means of increasing income (Diale, pers comm, 2010; PIKITUP, Annual Report, 2009/10).

As garden refuse sites are the main source of organic material, the state of the city's 42 garden refuse sites influences the quality and cost of compost produced. Unfortunately most garden refuse sites are unkempt, accept commercial waste and are home to many informal waste reclaimers, making cross contamination a serious problem. Furthermore, as the garden refuse sites were opened to assist local residents in the disposal of their garden waste, convenience, in terms of locality, was the overriding factor in the location of these sites. The result is that most are far away from the composting plant, significantly increasing transport costs (PIKITUP Annual Report, 2010/11).

\section{Findings}

The diversion of garden waste to the Panorama Plant has reduced waste haulage to landfills, although only some of the green organic material produced in the city reaches the plant. A systematic data collection process needs to be put in place in order to establish exactly how much waste is diverted, however. The contamination of the green organic waste by other types of solid waste makes for a poor quality end product and increases costs. Furthermore, the plant is not optimally used due to its own poor location and regular periods of equipment failure. Even if the plant was optimally used, however, it is too small to deal with all the green waste generated in Johannesburg. Although the Panorama Plant needs to expand, the city lacks the funds to do so. The Panorama Plant has created a few employment opportunities, especially for unskilled people. Progress has been made towards gender equity, as the plant no longer only employs men and the new female employees are not confined to office work only. The Panorama Plant is not financially sustainable as operational costs are high and sales are low (Lloyd, pers comm, 2010). This is partly due to a lack of a pre-launch detailed marketing analysis which means that the end product is poorly branded and marketed. Long-term markets have yet to be secured. This is in tandem with the findings for other parts of South Africa with respect to commercial composting by municipalities (Karani \& Jewasikiewitz, 2007).

\section{Discussion and recommendations}

As in the United Kingdom, the promulgation of environmental legislation successful promoted the development of composting facilities in Johannesburg (Slater \& Frederickson, 2001). Furthermore, it can be seen that the formal bringing together of multiple stakeholders, in this case, the Polokwane Declaration, helped generate a critical mass of people and organizations who publically committed themselves to sustainable development, with agreed-upon goals. Thus, political buy-in was a crucial factor in the establishment of this composting plant. Unfortu- 
nately, implementation of commercial composting in Johannesburg has met with a number of challenges, high costs being the most important. We suggest that small scale entrepreneurs, or waste reclaimers as they call themselves, who are already salvaging material from garden refuse sites or are working as gardening service enterprises, become involved in the commercial composting business to lower costs. Furthermore, garden refuse centres need to be better managed in order to prevent cross contamination of organic waste. An improved marketing plan for the end product is also required. For example, the city could highlight the 'greenness' of the product (environmentally friendly), the 'brownness' of the product (i.e. market it as a social responsibility product), and the 'value for money' (i.e. the city can choose to compete on price). Lastly, the city needs to invest in the supply chain to ensure the product is readily available to consumers, through major retail outlets and wholesalers. Other potential markets, such as construction contractors, golf-course managers and farmers, could also be explored.

\section{Conclusion}

The Panorama Composting Plant contributes positively to sustainable development as it does divert waste from landfill sites, but this is only on a small scale. Mechanisms to increase the rate of diversion need to be explored. Furthermore, although the composting plant does contribute to social and economic aspects of sustainable development, the scale is also limited. This is mainly due to the choice of a centralized, mechanized composting system by the City of Johannesburg. Thus, more labor-intensive technologies should be seriously considered to boost the number of job opportunities created. In particu- lar, we suggest Johannesburg partners with the small-scale entrepreneurs - who currently act as waste reclaimers and garden cleaning service operators - located at the various garden refuse sites and landfills, to create a new, micro-scale composting industry. This should both increase the number of people participating in the supply and marketing chain, and improve the rate at which green organic waste is diverted into composting. This should help the City of Johannesburg overcome some of its cost, marketing and transportation challenges, while simultaneously increasing employment and income generating opportunities in the city.

\section{Acknowledgements}

The authors thank Wendy Job of the UJ Cartographic Unit, Venessa de Boer for the language editing, the UJ library, and the following research assistants: Darryl Slawson, Livhuwani Ramalata and Julian Schmidt. We are also grateful to Dr Lukas Scheepers (now retired) for his insights into the thesis, on which part of this manuscript is based. We are also grateful to a number of PIKITUP staff and other composting experts in the Johannesburg area for their cooperation and insight. Thanks to the critical reviewers for insightful comments, especially Professor Cecil Seethal of the Department of Geography, University of South Africa. A version of this manuscript was presented at the Urban Geography Commission of the IGU, Living in a Changing Urban Landscape Conference, Johannesburg, South Africa 21-26 July 2013 and at the $12^{\text {th }}$ Annual Conference of the International Association for Impact Assessment, South African Affiliate, Pilanesberg, South Africa, 28-30 August 2006.

\section{References}

1. City of Johannesburg. (2003a). State of the Environment Report, Environmental Management Framework for the City of Johannesburg.

2. City of Johannesburg. (2003b). Status quo report on the current waste generation and management in the City of Johannesburg, Jarrod Ball Consortium.

3. Diale, G. (2010). Personal communication, Panorama Plant, Johannesburg.

4. Department of Environmental Affairs and Tourism. (2001). Polokwane Declaration on Waste Management, Department of Environmental Affairs and Tourism (DEAT).

5. Department of Water Affairs and Forestry. (1998). Minimum requirements for waste disposal by landfill, Waste Management Series, 2 (2), CTB Book Printers, Cape Town.

6. Deshmukh, S., Gupta, R. and Agrawal, V.S. (2002). Improving solid waste management by developing the people's perception, Wastecon International Waste Management Biennial Conference and Exhibition. 30 September-4 October, Durban, South Africa, proceedings, 1, pp. 368-371.

7. Des Ligneris, J. (2000). A new waste management strategy for the South African solid waste industry. Wastecon 2000 Biennial Conference and Exhibition. 5-7 September, Somerset West, near Cape Town, South Africa, proceedings, 1, pp. 285-92.

8. Drescher, S. and Zurburgg, C. (2006). Decentralized Composting: Lessons learnt and future potentials for meeting the Millennium Development Goals, Collaborative Working Group on Solid Waste Management in Low and Middle Income Countries, 72, pp. 1-9.

9. Ekelund, L. and Nyström, K. (2007). Composting of Municipal Waste in South Africa - sustainability aspects, Ritee Zecutech Sales and Service, 1, pp. 1-67. 
10. Fehr, M. (2007). Confirming decentralized composting as a definite option in urban waste management, International Journal: Environmental Technology and Management, 7, pp. 274-85.

11. Giggey, M.D., Gwebu, I.S. and Skoglund, T.E. (2000). Composting waste organics to save landfill space. Wastecon 2000 Biennial Conference and Exhibition. 5-7 September, Somerset West, South Africa, proceedings: 2, pp. 257-64.

12. Hoornweg, D., Thomas, L. and Otten, L. (1999). Composting and its applicability in developing countries, Urban Waste Management, Washington DC, Urban Development Division of the World Bank.

13. Karani, P. and Jewaskiewitz, S.M. (2007). Waste Management and Sustainable Development in South Africa, Environment, Development and Sustainability, 9, pp. 163-85.

14. Korner, I., Saborit-Sanchez, I. and Aguilera-Corrales, Y. (2008). Proposal for the integration of decentralized composting of municipal solid waste into the waste management system of Cuba, Waste Management, 28, pp. 64-72.

15. Lerner, J. (1995). Brazil: Curitiba’s “Voluntary Sustainability”, available at: www.sustainable.org/casestudies/ international/INTL af curitiba.html, accessed 10 September 2008.

16. Lloyd, H. (2010). Personal communication, Panorama Plant, Johannesburg.

17. Makhubela, R. (2010). Personal communication, Panorama Plant, Johannesburg.

18. Mbuligwe, S.E., Kassenga, G.R., Kaseva, M.E. and Chaggu, E.J. (2002). Potential and actual constraints of composting domestic solid waste in developing countries: findings from a pilot study in Dar-es-Salaam, Tanzania, $R e$ sources, Conservation and Recycling, 36, pp. 45-59.

19. Onu, C. (2000). Sustainable waste management in developing countries, Biennial Conference and Exhibition, 5-7 Sept, Somerset West, Cape Town, pp. 367-378.

20. Otieno, F.A.O. and Venter, C. (2004). A proposed framework for sustainable waste management in the City of Johannesburg, South Africa: Wastecon.

21. PIKITUP. (2007/8). Annual Report 2007/8, available online at: http://www.pikitup.co.za/upload/files/ PikitupAnnualReport2007_08_Final.pdf. Accessed 7 May 2012.

22. PIKITUP. (2008/9). Annual Report 2008/9, available online at: http://www.pikitup.co.za/upload/files/ Pikitup annual_report\%2008_09_LATEST_VERSION_v1.pdf. Accessed 18 April 2013.

23. PIKITUP. (2009/10). Annual Report 2009/10, available online at: http://www.joburg-archive.co.za/2011/annual-report0910/Annexures\%20-\%20Item\%2018/Annexure\%20H\%20-\%20Pikitup\%20Johannesburg/Pikitup\%20 Annual\%20 Report\%202009-2010.pdf. Accessed 18 April 2013.

24. PIKITUP. (2010/11). Annual Report 2010/11, available online at: http://www.joburg-archive.co.za/2011/annual report_1011/pikitup_annual_report11.pdf. Accessed 9 March 2013.

25. PIKITUP. (2011/12). Annual Report 2011/12, available online at: http://www.pikitup.co.za/upload/ files/Annual_Report\%20_2011_2012.pdf. Accessed 13 May 2013.

26. Republic of South Africa. (1996). South Africa, The Constitution (Act no. 108 of 1996), Government Printer, Pretoria.

27. Republic of South Africa. (2000). South Africa, Municipal Systems Act (Act No.32 of 2000), Government Printer, Pretoria.

28. Republic of South Africa. (2000). South Africa, Health Act (Act No.63 of 1977), Government Printer, Pretoria.

29. Republic of South Africa. (1998). South Africa, National Environmental Management Act (Act No. 107 of 1998 ), Government Printer, Pretoria.

30. Republic of South Africa. (2008). South Africa, National Environmental Management Act: Waste Act (Act No. 59 of 2008), Government Printer, Cape Town.

31. Shoemaker, G. (2010). Personal communication, PIKITUP.

32. Singo, J. (2010). Personal communication, Panorama Plant, Johannesburg.

33. Slater, R.A. and Frederickson, J. (2001). Composting municipal waste in the United Kingdom: some lessons from Europe, Resources, Conservation and Recycling, 32, pp. 359-74.

34. Troschinetz, A.M. and Mihelcic, J.R. (2009). Sustainable recycling of municipal waste in developing countries, Waste Management, 29, pp. 915-23.

35. Van de Klundert, A. and Lardinois, I. (1995). Community and Private (formal and informal) Sector Involvement in Municipal Solid Waste Management in Developing Countries, Background paper (draft) for Urban Management Program (UMP), Workshop in Ittigen, April.

36. Venter, C. (2006). Personal communication, PIKITUP.

37. Yiğiter, R.G. and Yirmibeşoğlu, F. (2011). Local Agenda 21 and sustainable development: The case of Harran, Turkey, Urbani izziv, 22 (1), pp. 144-153.

38. Zurbrugg, C.S., Drescher, S., Patel, A. and Sharatchandra, H.C. (2003). Taking a closer look at decentralized composting schemes - lessons from India, Asian Society for Environmental Protection, 1, pp. 1-10.

39. Zurbrugg, C.S., Drescher, S., Patel, A. and Sharatchandra, H.C. (2004). Decentralized composting of urban waste an overview of community and private initiatives in Indian cities, Waste Management, 24, pp. 655-62.

40. Zurbrugg, C.S., Drescher, S., Rytz, I., Sinha, A.H. and Enayetullah, I. (2005). Decentralized composting in Bangladesh, a win-win situation for all stakeholders, Resources, Conservation and Recycling, 43, pp. 281-92. 